\title{
OS MACUXIS RIEM COM O JABUTI OU DA TRAQUINAGEM AO QUESTIONAMENTO PELO RISO
}

\author{
THE MACUXIS LAUGH WITH THE JABUTI OR \\ FROM TRICKERY TO QUESTIONING BY LAUGHTER
}

Devair Antônio Fiorotti ${ }^{1}$

RESUMO: A partir principalmente de uma sequência de oito narrativas interligadas por uma risada do Jabuti, contadas pelo indígena macuxi Caetano Raposo, discute-se o riso e seus desdobramentos no contexto dessas narrativas. Além disso, busca-se leituras possíveis para o riso na organização social indígena macuxi, como o riso e seu aspecto questionador e de resistência diante da opressão.

PALAVRAS-CHAVE: Macuxi; Riso; Caetano Raposo; Jabuti.

ABSTRACT: Based mainly on a sequence of eight narratives interconnected by a laughter of the Jabuti (tortoise), told by the indigenous Macuxi Caetano Raposo, laughter and its unfoldings are discussed in the context of these narratives. In addition, possible interpretations for laughter are sought in the social organization of the Macuxi indigenous people, such as laughter as questioning and resistance in face of oppression.

KEYWORDS: Macuxi; Laughter; Caetano Raposo; Jabuti.

Aí [Jabuti] saiu, foi embora pro caimbezal. Aí encontrou, coco-babão, caroço de coco-babão embaixo da pedra.

Ficou quebrando aqui, Tah, e comendo. Aí Onça encontrou ele de novo: "Ê, camarada! Que que tá fazendo?" "Tô comendo caroço do meu saco." "Será que é gostoso caroço do seu saco?" "É gostoso. Quer provar?"

"Então me dê um." Tah! Deu pra Onça. "E aí?" "Tá gostoso". Deu outro de novo. "Assim também, o seu saco deve tá gostoso! Vamos experimentar?" O saco do gato, da Onça é atrás. "Então, senta aqui". Ele deu pedra, colocou pedra, aí onçazão e Jabuti: "Padauuuuuu", dois logo aí. "Heimmm"

"Hã'! Hã'! Hã'! Hã'! Hã! Hã'! Hã'! Hã'! Hã'! Hã! Hã'! Hã'! Hã'! [Caetano Raposo]

\footnotetext{
${ }^{1}$ Universidade Federal de Roraima - UFRR, Centro de Comunicação Educação e Letras, Departamento de Língua Vernácula, Programa de Pós-Graduação em Letras, Boa Vista, Roraima, Brasil; CNPq; https://orcid.org/0000-0002-1441-092X ; devair.fiorotti@ufrr.br
} 
Caetano Raposo foi um índio macuxi, liderança da Terra Indígena Raposa Serra do Sol. Ele faleceu em 21 de julho de 2016 e a entrevista ${ }^{2}$ que gerou os arquivos aqui apresentados e analisados, como a narrativa dessa epígrafe, para discutir a questão do riso, a partir de histórias de jabuti por ele narradas, foi realizada em Boa Vista, Roraima, local em que Raposo encontrava-se já em tratamento de saúde. Sua residência de nascimento e vida foi na comunidade da Raposa, na referida terra indígena, no meio do lavrado roraimense. ${ }^{3}$ Os macuxis são índios caribe (Santilli, 2001) e são a etnia mais numerosa de Roraima, presente em boa parte do estado na atualidade.

$\mathrm{Na}$ entrevista, além de falar sobre seu povo, sobre questões políticas, contar histórias, Raposo narrou uma sequência de oito histórias do ciclo do jabuti, sempre acompanhadas de uma risada performática do narrador, que interligava as histórias, unindo o término de uma ao início da vindoura. A expressão "O ciclo do jabuti" refere-se a uma série de narrativas sobre esse animal, de origem incerta, mas presente em muitas culturas, inclusive em continentes distintos (Hartt, 1988). O riso do jabuti, o riso do indígena, seu movimento questionador é o foco de estudo aqui.

A presença ativa de Caetano Raposo enquanto narrador-performer movimenta uma série de recursos no ciclo do Jabuti, mas nada de forma tão marcada quanto a risada que ao animalzinho ele atribui. Em boa parte das narrativas, o Jabuti apresenta-se como a corporificação da esperteza, tomando atitudes que, muitas vezes, beiram a crueldade. Dando sequência à narrativa da epígrafe,

[Achou graça] dele [da Onça], aí foi embora, saiu de lá. Foi embora, foi embora e aí encostou no poço. Aí tava brincando o Luar, por aqui assim, quando bate na água, o Luar [faz gestos com os braços]. Eles tavam brincando lá. Aí Onça disse: "Que que tá fazendo aí?" "Não, quero comer beiju, beiju de goma, beiju de goma. Tá lá dentro aí. Quero pegar ela, mas não tô podendo não. Tô mergulhando, mas meu fôlego não dá, não." "Aonde?" "Ali, olha. Tá ali." [apontando para dentro da água] "É mesmo! Eu vou lá!" "Vai, mas é fundo. Vamos amarrar pedra e aí tu vai ligeiro." Carumbezão ${ }^{4}$ tirou [fibra de] olho do buriti, amarrou pedra no pescoço dele. "Tu vai lá, compadre, tu vai lá e traga pra nós." Aí onçazão, "Tchibum!". Desceu ligeiro. Aí lá, matou, matou, enforcado e dentro d'água, matou. "Hã'! Hã'! Hã'! Hã'! Hã! Hã'! Hã'! Hã'! Hã'! Hã! Hã'! Hã'! Hã'! Hã'! Hã! [Risada alta e performática do narrador, na voz do Jabuti]

Esta atitude de crueldade repete-se em outras duas narrativas. Na narrativa, embora a mera presença da Onça já represente suficiente ameaça para a existência do Jabuti, pois ele é seu alimento na cadeia alimentar, a Onça não estabelece confronto direto com ele. Contudo, o Jabuti aproveita-se da Onça e a mata. Entretanto, a gargalhada do Jabuti reverbera não apenas ante o público, mas também no cerne da compreensão deste mesmo público a ponto de praticamente absolver o quelônio. Nas outras narrativas o conflito entre o Jabuti e outros animais maiores e seus predadores é estabelecido de imediato e ao Jabuti cabe apenas lidar com a situação que lhe é interposta. O que nos leva a afirmar que é esta risada que particulariza a narrativa de Caetano Raposo ante outras, pelo menos nenhum outro narrador do projeto Panton

\footnotetext{
${ }^{2}$ Dados da entrevista: Entrevistado: Caetano Raposo / Entrevistador: Devair Antônio Fiorotti / Assistente de entrevista: Marques Leandro Pereira da Silva / Local da entrevista: Boa Vista / Data da entrevista: 26/04/2014 / Transcritora: Sonyellen Fonseca Ferreira / Conferência de fidelidade: Devair Antônio Fiorotti / Copidesque: Devair Antônio Fiorotti / Duração: 2'03"26"'.A metodologia de trato com a narrativa ancora-se principalmente em Alberti (2004).

${ }^{3}$ Lavrado, espécie de savana.

${ }^{4}$ Carumbé é um tipo de jabuti, as palavras jabuti e carumbé são usadas pelo narrador como sinônimas.
}

Rev. Bras. Lit. Comp. Niterói, v. 22, n. 39, pp. 65-76, jan. /abr. 2020

https://doi.org/10.1590/2596-304X20202239df 
Pia' (www.pantonpia.com.br) nem mesmo da revisão bibliográfica realizada executam tal risada.

Já dizia Aristóteles em Partes dos animais (2010, p. 136) que o homem é o único animal que ri. Não apenas ri, como bem atalhou Henri Bergson (1983), como também faz rir e, muito embora sob o riso exista um apanágio de atitudes e sentimentos humanos, inclusive a crueldade, é pelo viés do cômico que este trabalho se desenvolve. Propp diz que, ainda que se ria de um animal, é em virtude de evocar a lembrança do homem ou de a ele assemelhar-se que se ri: "O cômico sempre direta ou indiretamente está ligado ao homem. A natureza inorgânica não pode ser ridícula porque não tem nada em comum com o homem" (1992, p. 38). Assim também o assegura Bergson, para quem o homem poderia ser definido como um animal que faz rir, diferentemente de outros animais (Bergson, 1983).

Não há comédia sem riso, já a recíproca não é verdadeira. Remontando novamente a Aristóteles de A poética (1974), o estagirita indica a gênese da comédia, gestada no ventre das artes da mimesis, na qual também se nutriu a tragédia, sendo uma diferente da outra pelo fato de esta imitar os homens melhores do que em realidade são, e aquela por imitá-los piores. Entretanto estes homens piores não o eram a ponto de imitarem todos os vícios, mas só os ridículos.

Mas se o homem é o único animal que ri, antes mesmo do homem, antes de tudo, veio o riso, como apresenta George Minois (2003, p. 23), citando parte do texto encontrado no século III, o papiro de Leyde. Deus deu sete gargalhadas de onde nasceram

os setes deuses: Luz, Água, Hermes, Geração, Destino, Tempo e, do choro do riso, a Alma. Já oito gargalhadas dá o Jabuti de Caetano Raposo entre uma narrativa e outra, que à primeira impressão parece configurar uma espécie de riso-refrão, que marca o término de uma e anuncia outra narrativa. Mas a cada repetição, um novo significado pode ser dado à risada do Jabuti. Fazendo rir o Jabuti, Caetano Raposo institui-se definitivamente enquanto narrador e estabelece um movimento incessante de aproximação e afastamento entre narrador-público e públicosentidos das narrativas.

O riso do Jabuti de Caetano Raposo faz rir, à primeira vista pela inusitada atribuição da capacidade humana de rir ao animalzinho. O riso acaba sendo uma reação diante do inesperado, uma vez que permite que se estabeleça um jogo intelectual com ele (Minois, 2003). Essa reação provoca distensionamento após o assustador encontro com a voraz Onça. Este jogo intelectual revela a faceta lúdica do riso do Jabuti, provocando excitação sensorial através da sonoridade da gargalhada. Talvez, por isso mesmo, ela encontre tão forte ressonância perante o público e, assim, o riso imprima profundamente em sua memória cognitiva e mesmo afetiva, quase não deixando tempo para que o público avalie racionalmente o significado daquele riso, já que o narrador encadeia oito histórias com ele.

O riso assim seria também um jogo lúdico cuja característica maior, de acordo com Johan Huizinga (2000), é o divertimento. A concepção de jogo de Johan Huizinga torna-se interessante quando se amplia para além do humano. Embora assuma o jogo enquanto fenômeno cultural, ele diz que o jogo começa mesmo antes da própria civilização. E ainda que esta concepção assuma o aspecto irracional do jogo enquanto divertimento, não se isenta de uma função significante. Partindo para a concepção de jogo já inscrito enquanto fenômeno cultural, Huizinga nos lembra que, dentro da cultura, o primeiro jogo estabelecido pelo homem foi a linguagem. $\mathrm{O}$ estudioso assim assume a linguagem enquanto um jogo constante entre a matéria e as coisas pensadas que ocultaria uma metáfora, um jogo de palavras.

Nas narrativas de Caetano Raposo, teríamos uma espécie de metajogo em que o Jabuti e a Onça, seres nascidos na/da linguagem, estabelecem outro jogo com o público através da performance do narrador, destacadamente pela risada imprimida ao Jabuti. Jogo viabilizado por 
passagens como na primeira narrativa de Caetano Raposo em que, narrando a subida do Jabuti no pé de inajá, dirige-se ao entrevistador e comenta: "Dizendo ele que subiu".

O Jabuti... Ele andou e encontrou macaco comendo inajá, os macacos comendo. Aí pediu [que o] Macaco derrubasse inajá pra ele. "Derruba inajá pra mim?!" Macaco derrubou. Comeu. Pediu outro. Macaco derrubou. Até que Macaco se enjoou dele. Aí ele veio: "Rapaz, eu vou te buscar lá, eu vou te deixar aqui em cima do pé de inajá." Aí colocou lá em cima, ficou comendo lá. Não demorou muito lá vem Onça. Onça veio e falou pra ele "O que é que o senhor tá fazendo aí?" "Não, eu subi aqui pra comer inajá." Dizendo ele que subiu. "Tá gostoso?" "Tá" "Então derruba um pra mim". Derrubou pra Onça. "Mas tá gostoso, mesmo!" Comeu. "Derruba mais um”. Comeu. "Derruba mais um”. Até que Jabuti pensou: "Rapaz, eu vou matar essa Onça." "Derruba mais um" "Então fica embaixo, na minha direção, bem embaixo de mim, mas pisca olho, não olha pra mim, não, pisca olho. Eu vou te derrubar inajá, pra você." Ficou aí piscado. Jabuti veio de lá e óhhh pá! E achou graça. Hã’! Hã’! Hã’! Hã’! Hã’! Hã’! Hã’! Hã’!

Esse jogo retórico e performático culmina com a risada do Jabuti, que mobiliza por sua vez o riso do público. É este jogo que estabelece o movimento de aproximação entre humanidades do performer e do público através do riso repentino que acaba por transformar-se em jogo interacional.

Em contrapartida, o riso apresenta certo distanciamento por parte de quem ri em relação à situação vivenciada, como assume Propp (1992, p. 31): "O riso ocorre em presença de duas grandezas: de um objeto de riso e de um sujeito que ri - ou seja do homem." Assim sendo, ao menos no plano narrativo, o Jabuti de Caetano Raposo é capaz de afastar-se do risco de morte iminente provocado pela presença da Onça, com sua risada final, numa espécie de exorcismo do medo. Ao mesmo tempo esse afastamento também é possível ao público, além de ser-lhe proporcionada, ainda que temporariamente, a possibilidade de libertar-se do medo da Onça, pela ruptura da lógica da cadeia alimentar, da subversão dos papéis exercidos desde os tempos imemoriais por predador e presa.

Essa subversão avia os caminhos da comicidade das fábulas do Jabuti porque possibilita no plano narrativo aquilo de que é impossível desvencilhar-se no plano real, causando uma espécie de riso catártico que aproxima narrador-personagem e público pelas vias da comicidade. Libertando-se do medo da Onça e rindo dela, o público liberta-se e ri também do medo da morte, extinguindo, ainda que simbólica e momentaneamente, a própria morte. O homem então pode rir e libertar-se da consciência daquilo que é inexorável à sua existência: o tempo, a memória e a morte. O riso ganha um status humanizador, pois nos lembra que tanto Jabuti quanto Onça e homem estão sob as mesmas leis naturais. Assim temos um movimento de aproximação. Do rir de alguém passamos a rir com alguém, criando reverberação ou, como bem percebeu Bergson (1983), o riso precisaria de eco, se prolongaria, se repercutiria como estalos de trovões nas montanhas.

Suassuna aponta para dois recursos fundamentais ao riso: o de localizar as personagens enquanto seres de linguagem; e o de estabelecer um gesto cômico ao mesmo tempo em que a ação possivelmente prejudicial se desenvolve. Estes dois recursos são perceptíveis ao longo das narrativas de Caetano Raposo. Em um momento, porque Caetano Raposo é interpelado a contar as histórias do Jabuti por um entrevistador. Logo o público de antemão sabe que trata-se de uma recriação da realidade. Em um segundo, pois no desenrolar da ação nas histórias, o Jabuti sempre leva a melhor, causa a morte como na narrativa com a Onça, apesar de ser mais frágil.

O riso atribuído ao animalzinho, ainda, é uma recriação. A essa recriação, Ariano Suassuna define de riso estético: “Aquele tipo de Risível recriado ou possível de ser recriado 
pela Arte riso do qual as principais categorias são o Cômico e o Humorístico" (Suassuna, 2008, p. 143, com iniciais maiúsculas no original). Partindo da definição de recriação que abrange o riso estético, temos nas narrativas de Caetano Raposo a atribuição de ações e da capacidade de fala aos animais, num processo de máscara, prosopopáico. Ao término da narrativa e da investida contra a Onça há o riso. O riso então seria um gesto que distanciaria o público das possíveis consequências dolorosas da ação do Jabuti contra a Onça, o que anularia a crueldade das ações, já que distanciaria o público do sofrimento causado à Onça.

Como nas narrativas em que o Jabuti encontra a Onça brincando na laje de pedra, observando a lua refletida na água, há momentos em que o riso torna-se incômodo e constrangedor. É quando o caráter puramente cruel do Jabuti demonstra-se. Contudo, o próprio Suassuna, ao analisar a concepção de Hobbes sobre o riso e mais tarde a de Stendhal, aceita a crueldade enquanto elemento na forma com que se ri dos outros. Não há embate claramente estabelecido entre os dois velhos rivais, mas ainda assim o Jabuti abate a Onça. Contudo, há um embate na cadeia alimentar natural em que o animal mais frágil torna-se comida. Há um embate inclusive entre os tamanhos dos animais, de que a história não trata às claras, porém que está presente em quem ouve a história e, principalmente, em quem narra, que profere a risada sarcástica. Risada que revela muito mais do que o simples riso: mas um ambiente irônico em que o mais forte perde, por meio da astúcia do menor, do mais frágil a priori, que o Jabuti representa.

$\mathrm{O}$ ato de maldade poderia resultar em uma antipatia do público para com o Jabuti, entretanto o estatuto ficcional relacionado ao riso não permite isso, tanto que o Jabuti e a Onça tornam a encontrar-se e a enfrentar-se noutro momento dentro da sequência narrada por Raposo, em que novamente acontece a morte da Onça, demonstrando aquilo que Ariano Suassuna aponta na teoria de Aristóteles: a falta de consequências dolorosas na ação: o ambiente cômico, do riso, as regras do jogo pela linguagem (o entrevistador pede: conta-me histórias de jabuti), o ficcional. Estes recursos evidenciam a existência de Jabuti e Onça enquanto seres de linguagem, libertando o público das consequências reais da existência desses animais, em especial da Onça, no mundo biossocial.

Ainda de acordo com a definição do riso estético, o riso do Jabuti apresenta-se como recriação perante outras narrativas cujas semelhanças temáticas e/ou de sentidos se apresentam. Como quando comparamos as narrativas coletadas por Theodor Koch-Grünberg (1981) ou mesmo com a narrativa de Esopo A tartaruga e a lebre. Comparada a esta, a narrativa de Caetano Raposo acerca da corrida entre o Jabuti e o Veado Galheiro, apresenta consideráveis diferenças, embora mantenha a semelhança temática em que um animal extremamente veloz estabelece uma competição com um animal muito vagaroso. $\mathrm{O}$ riso do Jabuti dado contra $\mathrm{o}$ Veado corredor parece subverter a moral ortodoxa da fábula esópica. Na narrativa de Caetano Raposo temos uma competição em que a esperteza e a colaboratividade entre os jabutis são as grandes vencedoras, como se vê abaixo:

Oh, compadre! Saiu e aí foi embora. Aí encontrou com Veado. Disse: "Você é corredor?" "Sou corredor, eu sou corredor, disse o Veado, e você?" "Eu também sou corredor." "Então vamos experimentar nossa carreira?" "Vamos." "Tal dia?" "Tá bom." "Nós vamos sair daqui. Aqui tá o igarapé, você fica d'outro lado e eu fico d'outro." "Tá." Aí convidou outros carumbés, companheiros dele. "Tu fica aqui, quando veado perguntar de ti, diga que você tá na frente." Colocou outro mais na frente, assim.

DF: Uma sequência de jabutis. 
CR: Eh, de jabutis. Aí chegou o dia deles. Aí o veado perguntou: "Já, compadre?" "Já, compadre, vamos embora!" Saíram. Veado saiu torto daí. Aí perguntou: "Compadre?" "Erhmm!" Responderam lá na frente. Veado é bicho todo [esperto], carreira do Veado é de 80 quilômetros por hora.

DF: É ligeiro.

CR: "Compadre!" "Erhmm!" Lá na frente. Foi embora, foi embora, foi embora, foi embora, compadre foi embora. "Compadre!" "Erhmm!" Veado cansou, diminuiu carreira. Chegou no ponto deles lá, lá ele estava.

DF: Lá no final?

CR: Lá no final, estava lá.

DF: E descansado ainda? [Risos]

CR: Eh, descansado. [Risos] "Cheguei muito perto, compadre." "Eu não falei que eu sou corredor?" "Tá bom, compadre." Vieram com a língua desse tamanho, assim.

DF: Do lado de fora?

CR: Cansado, cansado, cansado. Aí o Carumbé achou graça dele "Hã'! Hã'! Hã'! Hã'! Hã'! Hã'! Hã'! Hã'! Hã'! Hã'! Hã'! Hã'! Hã'! Hã'! Hã'!".

Ainda, nessa e nas outras narrativas apresentadas aqui neste texto e nas outras que compõem a sequência de oito pantoni (histórias do povo macuxi) proferidas por Caetano Raposo, o que destaca-se é o riso de zombaria ou escárnio, importantíssimo para a compreensão de obras literárias, de acordo com Vladimir Propp (1990, p. 28). Partindo de seu estudo acerca do riso de zombaria, Propp o baseia como objeto da derrisão e para cada objeto haveria meios mais específicos e outros mais gerais, dentre os quais, o teórico elenca o de fazer alguém de bobo, ação bastante provocada pelo Jabuti contra a Onça.

Propp recorre a um termo russo para definir a ação de fazer alguém de bobo, odurátchivanie. Em nota de rodapé da tradução brasileira, o termo russo carrega em si além do sentido de logro ou engabelo, a manifestação da própria imbecilidade por parte da vítima do odurátchivanie. Ou seja, a vítima compartilha a culpa pela situação de engodo. Propp diz que o procedimento do odurátchivanie constituiria fundamento de comédias e de narrativas, sendo que a vítima de odurátchivanie poderia "se tornar tal por sua própria culpa. O antagonista valese de algum defeito ou descuido da personagem para desmascará-la para escárnio geral." Haveria situações, porém, em que aquele que é ludibriado pode nãos ser "culpado embora todos riam dele" (Propp, 1990, p. 99-100).

Pensando próximo a Propp, o Jabuti atuaria no sentido de revelar a ignorância como defeito mortal da Onça, ideia que circula entre os depoimentos de indígenas como Clemente Flores, taurepang da comunidade Sorocaima I, ao rir de quando os irmãos Macunaima enganam a Onça: “Também, Onça é besta, né?” (Fiorotti, 2019, p. 30). Essa interpretação talvez seja uma percepção de que o apego a desejos ou mesmo atitudes cria obsessões que nos afastam do padrão aceitável, mesmo em relação à esperteza. Tornando a odurátchivanie, Propp (1990) indica que sua presença é sustentáculo fundamental das comédias que vão do teatro de marionetes, passando pela commedia dell' arte italiana e pelas comédias de Shakespeare. 
Também servindo de sustentáculo ao folclore cômico e narrativo, as anedotas, populares, facécias, Schwanke, fabliaux, assim como os contos maravilhosos de animais e os satíricos. Propp aponta para o fato de que mesmo em narrativas folclóricas, há subjacentes sátiras sociais em que os enganados são representantes das classes que oprimem e exploram o povo.

Por trás do riso do Jabuti, há o riso de Raposo, entremeado por vários discursos resultantes do contexto sócio-histórico conflituoso entre os macuxis e os não-índios, mesmo da origem incerta das histórias do jabuti. Assumindo o ciclo do jabuti como uma metáfora dessas relações, pode-se interpretar o riso não como sujeição às necessidades, mas como denúncia e resistência às relações estabelecidas em virtude de tais necessidades e à possível naturalização delas.

Paulo Santilli, em "Riso castiga os costumes" (2010), admite o riso enquanto "princípio político pervasivo, que incide sobre as esferas da hierarquia e da reciprocidade, ou, de modo mais amplo, sobre a estrutura social, trazendo à tona o valor da autonomia pessoal" $(2010, \mathrm{p}$. 106). Embora atenha-se às relações de parentesco e afinidade no âmbito da aldeia, Santilli traz considerações interessantes quando ampliadas ao contato com o não-índio. O estudioso aponta para o fato de o riso ser um princípio de sociabilidade que perpassa o conjunto das relações sociais. Assim, o riso e aquele que faz rir teriam, dependendo de sua posição hierárquica na família ou aldeia, um duplo papel de aproximar os indivíduos como o de afastar, afim de estabelecer a primazia dos indivíduos sobre as relações sociais pelas quais se organizam, obedecendo ao princípio de igualdade.

Els Lagrou, em "Rir do poder e o poder do riso nas narrativas e performances kaxinawa" (2006), analisa as narrativas míticas e performances entre os Kaxinawá e mostra as relações entre o humor e o conhecimento nativo sobre o mundo. Ela também admite o riso enquanto socialidade e agência ritual entre as pessoas e o mundo animado. O riso então seria um poderoso instrumento de captura do outro, seja outro gênero ou outra cultura, e da perspectiva do outro em prol da manutenção da harmonia. Diz ainda que o rir do outro, principalmente do estrangeiro ou do que pertence à outra cultura, é uma forma de aproximar-se dele para melhor ser a si mesmo numa espécie de devir em que o outro pode se tornar como nós mesmos e o mesmo se tornar o outro (2006, p. 72).

Pierre Clastres em "De que riem os índios" (2012) traz dois mitos dos Chulupi, índios que vivem ao sul do Chaco paraguaio. O primeiro tem como personagem principal um velho xamã confuso e concupiscente que empreende uma expedição em busca da alma do bisneto. $\mathrm{O}$ segundo traz a figura do tolo jaguar que também empreende uma viagem cheia de imprevistos. Como afirma Clastres (2012, p. 160), "Esses dois mitos apresentam xamãs e jaguares como vítimas de sua própria estupidez e de sua própria vaidade, vítimas que por isso merecem não a compaixão, mas o riso". Clastres também pontua que essas não são as principais causas do riso provocado por xamã e jaguar quando analisa-se a posição de ambos na relação vivida que mantêm com os índios, já que "longe de serem personagens cômicas, ambos são ao contrário seres perigosos, capazes de inspirar o medo, o respeito, o ódio, mas nunca a vontade de rir" (2012, p. 160). Clastres diz que os índios riem do que temem e, então, o riso admite um caráter simbólico poderoso. Sendo impossível realizar na esfera do real, é no plano narrativo que se dá cabo ao que se intenta: matar o medo.

Trata-se pois, para os índios, de colocar em questão, de desmistificar a seus próprios olhos o medo e o respeito que lhes inspiram jaguares e xamãs. Esse questionamento pode operar-se de duas maneiras: seja realmente, e mata-se então o xamã julgado muito perigoso ou o jaguar encontrado na floresta; seja simbolicamente, pelo riso, e o mito (desde então instrumento de desmistificação) inventa uma variedade de xamãs e jaguares tais que se possa caçoar deles, já que são despojados de seus atributos reais para serem transformados em idiotas da aldeia (Clastres, 2012, p. 162). 
Clastres aponta duas possibilidades para eliminar o que causa medo, contudo é o riso que nos interessa aqui: o riso torna-se um equivalente da morte, o ridículo passa a ter um potencial letal e o que tem de ser ridicularizado é o que causa mais temor. Diz Clastres que haveria uma função catártica do mito, ao liberar na narrativa certa paixão dos índios, em rir do que se teme, ensinando que "entre os índios, o ridículo mata. (2012, p. 163)

Rir do que causa medo, esse parece ser o foco da fala de Clastres, em relação aos indígenas. Em Roraima, o livro literário que mais forte apresenta o confronto entre índios (não só macuxis, apesar de o livro tratar deles) e karaiwa (não índios) é Xипипи tamu, de José Vilela (1998), sobre a comunidade indígena Santa Cruz. O livro é fruto de uma intensa vivência entre Vilela e os indígenas daquela comunidade, chamada no livro de Xununu Tamu. Ele narra os problemas enfrentados pela maloca, causados pelo fazendeiro Newton Tavares e pelas próprias instituições roraimenses da época que não reconheciam (e ainda pouco reconhecem) os direitos dos povos originários de Roraima (Fiorotti e Ferreira, 2018). Lendo o livro, sempre impressionou-nos que, mesmo diante das maiores adversidades, os índios muitas vezes riem. Como exemplo, depois de ter a casa queimada pelo fazendeiro, com todos os pertences dentro, a personagem Ulalá

[...] murmurou, olhando para o azul celeste:

- Eu vou fazer outra... [casa]

Balbuciou e riu. E os outros índios riram também. E as crianças já brincavam de jogar pauzinhos no fogo. (Vilela, 1998, p. 182)

Ou quando, depois de serem deixados, cansado e com fome, no meio do mato por um caminhão:

[...] O caminhão deu ré e se mandou, deixando tufos de fumaça para trás.

Os macucos sentaram no pé da serra e riram daquela desventura. Estavam cansados e com fome. E resolveram montar guarda no monte de palha até conseguirem transporte para terminar o serviço começado. (Vilela, 1998, p. 158)

Em 2019, em uma disciplina do Mestrado em Letras da UFRR, Devair Antônio Fiorotti discutiu essa obra e levou Vilela para conversar com os alunos. Fiorotti perguntou por que os indígenas, na obra, riem tanto. Vilela disse que, no contato com eles que gerou a obra, quando narravam os acontecimentos mais terríveis que a comunidade havia enfrentado, o riso estava sempre presente, inclusive porque, ao final, eles foram vencedores, tiveram seu direito sobre a terra reconhecido. Como o Jabuti, apesar de serem mais fracos, os índios riem. Ainda riem, pensando com Clastres, para ridicularizar o que causa tanto mal, opressão sobre eles.

Bakhtin, na obra sobre Rabelais trabalha com uma inversão de papéis em que a opressão pode ser questionada, por meio do riso, principalmente carnavalesco e popular (1993). Essa reversibilidade oriunda do riso é muito presente na obra de Vilela, em que o mais fraco, mesmo às vezes num primeiro momento frágil e derrotado, consegue sorrir do inevitável imposto pela vida. $\mathrm{O}$ riso, nesse sentido, questiona o poder e mesmo o que pode apresentar vitória: lendo a obra de Vilela e mesmo a realidade atual indígena, eticamente e moralmente somos impelidos a ficar do lado dos indígenas, pois o etnocídio a que os povos indígenas foram e estão sendo submetidos desde a invasão europeia é um dado triste de nossa história (Fiorotti e Ferreira, 2018).

O riso do Jabuti de Caetano Raposo, o riso das personagens na obra de Vilela criam um movimento de aproximação e também uma espécie de cumplicidade entre público e Jabuti e mesmo com os indígenas atacados em Хипипи tати, pois o público pode apreciar a narrativa 
enquanto sátira social em que a Onça é, numa analogia com os personagens da realidade social dos povos indígenas, encarnada como os a priori mais fortes na comunidade, também os fazendeiros, e por isso mais abastada e forte, porém derrotada.

Ao Jabuti, cabe também a empatia do público que, através do animal, consegue sentir-se justiçado dos séculos de espoliação e dizimação de sua gente e cultura. O riso passa a ser então reflexão sobre os conflitos sociais vivenciados a partir do contato com a cultura não-indígena, como tão bem e tragicamente apresenta Хипипи tати. Assim, rindo, Caetano Raposo ri junto com o jabuti ao mesmo tempo em que constrói o riso dele, o de si mesmo e o de seu povo diante do opressor. Na leitura simbólica, o riso impede que se cristalize a hierarquia em que o nãoíndio ocuparia posição superior ante o índio.

Esta perspectiva, porém, nos sugere uma outra mais pungente, a contraface cruel do ceticismo. George Minois (2003) ao analisar o riso na comédia de Aristófanes entrevê o desejo de provocar a reflexão acerca do cenário político que desenvolvia-se na Grécia por volta dos fins do século V a. C. Contudo, ao contrário do que aparentava ser, o riso em Aristófanes, de acordo com o autor, não era revolucionário e, sim, conservador, buscando manter a ordem social antiga (Minois, 2003, p. 40).

Esta perspectiva também insinua-se quanto ao riso do Jabuti, de Caetano Raposo: a de que o riso denunciaria uma situação não para criticá-la em sua injustiça, mas para acusar aqueles que provocam insubordinação às normas vigentes, relegando ao ridículo a tentativa daqueles que buscam modificar as posições hierárquicas. O riso transforma-se numa espécie de concessão temporal em que é possível afrouxar as rédeas das convenções e opressões sociais, apenas para voltar a elas com fôlego suficiente para suportá-las até o próximo momento em que o riso seja novamente permitido tal qual válvula de escape.

Este ceticismo pode ser notado principalmente na relação dos indígenas das gerações mais novas face aos mais velhos, que os têm levado à negação dos costumes, língua e tradições de seus povos em virtude do contato com o não-índio e suas tecnologias. Isso é patente na fala de Lucinézio Peres Ribeiro, comunidade Santa Rosa, TI São Marcos, para o Projeto Panton Piá:

[...] o que a gente vê hoje é que a tecnologia vai derrubar um pouco, assim, um pouco da tradição indígena. Aqui na comunidade, uns tempos atrás os alunos faziam dançar muito o parixara, de vez em quando apresentavam fora, hoje não, hoje já pararam de dançar parixara. A tradição já tá ficando pra trás, estão esquecendo. Então, já assim da tecnologia, os alunos vão começar a fazer curso agora, a gente vai fazer curso de informática. Antão vão com certeza abrir outras ideias, vão ter outras ideias na frente e vão esquecer da tradição indígena, hoje. (Fiorotti, 2019, p. 234)

Fala reiterada por Aristides Macuxi da comunidade Sabiá:

Entonces, é por aí que nós temos, que às vezes, muitas vezes nós perdemos nossas tradições devido ao branco; perdemos aquela nossa cultura e tal. Não interessa mais hoje, porque os jovens nossos, não têm uma língua Macuxi pra ensinar àquelas crianças. Hoje nós queremos pagar uma professora pra levantar nossas crianças com aquela língua, que melhor de aprender é quando tá começando a falar. ${ }^{5}$

\footnotetext{
${ }^{5}$ Projeto: Panton pia' / Entrevistado: Aristides Macuxi (AM) / Entrevistador: Devair Antônio Fiorotti (DF) / Assistente de Entrevista: Huarley Mateus do Vale Monteiro / Local: Comunidade Sabiá, TI Alto São Marcos, Pacaraima, RR / Data da Entrevista: 6/4/2009 / Transcritora: Keyty Almeida de Oliveira / Conferência de Fidelidade: Devair Antônio Fiorotti / Copidesque: Devair Antônio Fiorotti / Duração: 57' 14"' [Narrativa ainda inédita]
}

Rev. Bras. Lit. Comp. Niterói, v. 22, n. 39, pp. 65-76, jan. /abr. 2020 
Ou ainda temos uma fala do macuxi Eduardo Magalhães também da comunidade Santa Rosa:

Tudo isso existia [tradições de cura para caçar, por exemplo]. Hoje, como a gente tá falando, já tá mais... o pessoal não tá mais ligando. Tá ligando mais é pra televisão mesmo, jornal. Ninguém quer mais saber de flechar, fazer... De primeiro, curumim desse tamanho vai querer saber de ficar fazendo flecha pra, fazendo caniço pra ir pescar... Hoje é difícil, é difícil fazer isso (Fiorotti, 2019, p. 198)

Apesar de todo ceticismo presente nessas falas, em que haveria um riso maior a consumir o riso metafórico do indígena, já que a cultura indígena estaria sendo minada pela forma brutal com que o contato genocida está ocorrendo desde a chegado dos europeus, Caetano Raposo apresenta uma forma astuta, para lembrar o Jabuti, de lidar com o outro sem deixar a si:

Eu quero aprender, eu sou gente, eu sou gente, eu quero aprender. Porque o branco tem, eu quero ter, também. Eu não quero ficar o tempo todo ali como índio, no chão, no pó, não. Então, eu penso diferente, eu quero que o meu povo aprenda que são índio, mas ninguém não vai esquecer a nossa cultura nem tradições, ninguém esquece, não. Nós somos índios, vamos tomar caxiri, vamos comer damorida, ninguém esquece, não. Eu penso assim. [...] Hoje eu vejo, agora diferente, todo ano o mundo muda e os brancos acompanha e eu lá sem saber de nada? Pra passar fome, pra passar necessidade? Não! Não quero não! Eu quero acompanhar. [...] Hoje tem vacina 11 horas, nós vamos descer pra tomar vacina, injeção no meio dos brancos, fazendo aquilo ali. Então doutor, eu quero assim: índio, índio, mas é gente, inteligente. Eu sou índio, mas gente inteligente, nós somos. Quero viver assim, eu sou índio, ninguém tira não, minha cara. Não tem pelo, não tem pelo, não tem nada. [...] É diferente, não tem nada não. Eu sou índio, com o meu idioma eu falo mais do que português. É prática, índio. Então, eu quero viver assim: índio, índio civilizado. Eu sou civilizado, tenho o documento aí, tenho o documento, eu voto como qualquer um brasileiro, eu sou brasileiro, eu me entendo assim. Eu sou índio, mas eu sou brasileiro, brasileiro nativo, roraimense nativo daqui. Eu gosto, eu gosto quando me chamarem índio. Não me chamem de caboco, eu falo sempre pros brancos, não me chama de caboco. Porque caboco entende, é filho do branco com índia, é caboco. Agora com índio mesmo puro, é índio. Pode me chamar de índio, aí eu me encho de orgulho aí, quando me chamam de índio. Opa! Eu sou índio. Porque índio? Isso é que conta, que conta, índio, conta, pronto. Tá dizendo que ele é índio. Então eu sou é índio, não sou caboco não, eu sou índio, sou índio. Então é por aí assim, começamos a escola da Raposa, hoje a Raposa tá aí diferente, muitos índios já saíram ali da Raposa pra ensinar o povo como professor. Que a primeira escola que chegou na Raposa, ninguém queria.

Em sua fala, Caetano Raposo deixa claro o desejo ao acesso a bens materiais produzidos pelos não-índios, pelos "brancos"; aos serviços públicos proporcionados pelo estado nacional; mas sem deixar de lado os bens culturais, a língua e a tradição indígenas. Esse acesso, a partir da fala de Caetano, retiraria os indígenas de condições consideradas inferiores, de fome e condições de vida precárias e principalmente de falta de reconhecimento enquanto cidadão 
brasileiro. Nisso residiria o paradoxo ser-índio e não-ser-índio sob a perspectiva de quem teve acesso aos dois lados envolvidos na relação entre índios e não-índios. Reflete também sobre as acusações de perda de identidade que sempre são feitas contra os indígenas que buscam o acesso à sociedade nacional.

Vimos como o riso está presente no ciclo de narrativas proferido por Caetano Raposo, como um objeto performático a partir do a priori frágil Jabuti e mesmo na vida dos indígenas ou em obras como Хипипи Тати. O riso do Jabuti, o riso do Raposo, o riso dos índios trazem um apelo a ser lido, entendido e, mais, um apelo quanto ao reconhecimento das especificidades indígenas ao mesmo tempo em que questiona a relação de poder existente nos dias atuais. $\mathrm{O}$ riso do Jabuti, talvez seja antes de tudo e depois de mais nada, resistência. A resistência perante o genocídio imposto desde a invasão colonizadora que infligiu a morte, o medo e a miséria aos povos indígenas e continua a querer impor-se desde então.

$\mathrm{O}$ riso, em seu papel questionador, é ainda uma forma de reivindicar o direito à dignidade da vida humana e a perspectiva indígena que, assim como qualquer outro povo, anseia pela garantia de seus direitos básicos, presentes na Constituição Nacional e em tratados de que o Brasil é signatário. Longe dos grandes centros, o riso indígena se propaga nas malocas enquanto uma forma de resistência e mesmo sobrevivência, como ensina Raposo. Contudo esse riso tem de ser reconhecido e respeitado em sua força criadora: seja enquanto o performer-artistaRaposo, seja naquilo que ele pode denunciar de opressão sobre os indígenas no Brasil.

\section{REFERÊNCIAS}

ALBERTI, Verena. Manual de história oral. 2. ed. Rio de Janeiro: Editora FGV, 2004. ARISTÓTELES. Partes dos animais. Tradução de Maria de Fátima de Sousa e Silva e consultoria científica de Lucas Angioni. Lisboa: Centro de Filosofia da Universidade de Lisboa / Imprensa Nacional-Casa da Moeda, 2010.

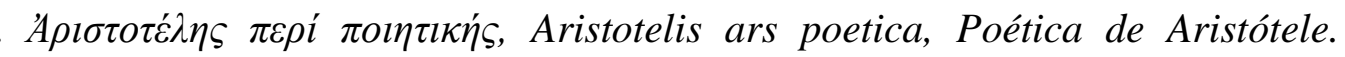
Edición trilingüe por Valentín García Yebra. Editorial Credos, Madrid, 1974.

BAKHTIN, Mikhail. A cultura popular na idade média e no renascimento: o contexto de François Rabelais. São Paulo, Brasília, EdUNB, 1993.

BERGSON, H. O riso. Rio de Janeiro: Zahar Editores, 1983.

CLASTRES, Pierre. De que riem os índios. In: A sociedade contra o Estado: pesquisas de antropologia política. São Paulo: Cosac Naify, 2012.

FIOROTTI, Devair Antônio. Panton pia': Registro na Terra Indígena São Marcos. Vol. I. Boa Vista: UERR edições; Wei, 2019. Disponível em https://pantonpia.com.br/wpcontent/uploads/2019/01/ebook-narrativa-oral-indigena.pdf Acesso 26/01/2020.

. FERREIRA, Sonyellen Fonseca. Xununu Tamu: um genocídio contra indígenas que não termina. In DORRICO, Julie; DANNER, Leno Francisco; CORREIA, Heloisa Helena Siqueira; DANNER, Fernando (Orgs.) Literatura indígena brasileira contemporânea: criação, crítica e recepção [recurso eletrônico] / Julie Dorrico; Leno Francisco Danner; Heloisa Helena Siqueira Correia; Fernando Danner (Orgs.). Porto Alegre, RS: Editora Fi, 2018. Disponível em <https://docs.wixstatic .com/ugd/48d206_093effa656194602b2bb25561277a65d.pdf> Acesso: 30/04/ 2019.

HARTT, Charles Frederik. Os mitos amazônicos da tartaruga. São Paulo: Editora Perspectiva, 1988.

HUIZINGA, Johan. Homo Ludens. Editora Perspectivas S.A. $4^{\text {a }}$ ed. São Paulo, 2000.

KOCH-GRÜNBERG, Theodor. Do Roraima ao Orinoco: observações de uma viagem pelo norte do Brasil e pela Venezuela durante os anos de 1911 a 1913. Vol. I. Trad. Cristina Camargo Alberts-Franco. São Paulo: Unesp/Instituto Martius-Staden, 2006. 
Del Roraima al Orinoco: observaciones de un viaje hecho por Teodor KochGrünberg por el Norte de Brasil y Venezuela durante los años de 1911 y 1913. Tomo II. Caracas, Ernesto Armitano, 1981.

LAGROU, Els. Rir do poder e o poder do riso nas narrativas e performances kaxinawa Revista de antropologia, São Paulo, USP, 2006, v. 49 nº 1.

MINOIS, George. História do riso e do escarnio. Trad. Maria Elena O. Ortiz Assumpção. São Paulo: Ed. UNESP, 2003.

PROPP, Vladimir. Comicidade e riso. São Paulo: Editora Ática, 1992.

SANTILlI, Paulo. Pemongon Patá: território Macuxi, rotas de conflito. São Paulo: Editora Unesp, 2001.

. O riso castiga os costumes. In Roraima: homem, ambiente e tecnologia. Boa Vista: FEMACT, 2010.

VILELA, José. Хипипи tamu, Cuiabá: Edição do autor, 1998.

Declaração de autoria e responsabilidade pelo conteúdo publicado

O autor declara que Sonyellen Fonseca Ferreira, doutoranda em Estudos de Literatura (UFF), ORCID 0000-0002-5790-7274, teve acesso ao corpus de pesquisa e participou ativamente da elaboração deste artigo.

Devair Antônio Fiorotti é docente do Departamento de Língua Vernácula da Universidade Federal de Roraima e pesquisador do CNPq. Autor e coautor de 19 artigos em periódicos, 21 capítulos de livros e 14 livros publicados, entre os quais Panton pia: Registro na Terra Indígena São Marcos (Boa Vista: Universidade Estadual de Roraima/ Edições e Wei, 2019). Informações completas em http://lattes.cnpq.br/8862097825581614

Submetido em 30/11/2019

Aceito em 02/01/2020

Rev. Bras. Lit. Comp. Niterói, v. 22, n. 39, pp. 65-76, jan. /abr. 2020 